\title{
Stability and virucidal efficacies using powder and liquid forms of fresh charcoal ash and slaked lime against Newcastle disease virus and Avian influenza virus
}

\author{
Sakchai Ruenphet ${ }^{1}$, Darsaniya Punyadarsaniya ${ }^{1}$, Tippawan Jantafong ${ }^{1}$ and Kazuaki Takehara ${ }^{2}$
}

\author{
1. Department of Immunology and Virology, Faculty of Veterinary Medicine, Mahanakorn University of Technology, \\ Thailand; 2. Department of Veterinary Medicine, Laboratory of Animal Health, Faculty of Agriculture, \\ Tokyo University of Agriculture and Technology, Japan. \\ Corresponding author: Sakchai Ruenphet, e-mail: rsakchai@hotmail.com \\ Co-authors: DP: darsaniya_p@yahoo.de, TJ: jantafong1980@gmail.com, KT: takehara@cc.tuat.ac.jp \\ Received: 23-07-2018, Accepted: 14-11-2018, Published online: 02-01-2019
}

doi: 10.14202/vetworld.2019.1-6 How to cite this article: Ruenphet S, Punyadarsaniya D, Jantafong T, Takehara $\mathrm{K}$ (2019) Stability and virucidal efficacies using powder and liquid forms of fresh charcoal ash and slaked lime against Newcastle disease virus and Avian influenza virus, Veterinary World, 12(1): 1-6.

\begin{abstract}
Aim: The present study was examined the virucidal activity comparison between fresh charcoal ash (FCA) and slaked lime (SL) against avian influenza virus (AIV) and Newcastle disease virus (NDV), using powder and liquid forms, either in the absence or presence of organic materials. In addition, both FCA and SL were evaluated for the persistence of virucidal activity in wet and dry conditions and stability of the solution.

Materials and Methods: Two hundred milligrams of FCA or SL powders were mixed with $100 \mu$ of AIV or NDV in the absence of organic material or $33 \%$ of organic materials. In the same time, $400 \mu 1$ of $1 \%, 5 \%$, or $10 \%$ solution samples were mixed with $100 \mu \mathrm{l}$ of each virus and then incubated at room temperature for an indicated time. After that, the mixed solution was stop activity of sample using $500 \mu \mathrm{l}$ of $1 \mathrm{M}$ Tris- $\mathrm{HCl} \mathrm{pH}$ 7.2. Each treatment was titrated onto Madin-Darby canine kidney cells or chicken embryo fibroblasts for AIV or NDV, respectively, for determining the efficacy of viral inactivation. In addition, the stability of powder under the wet-dry condition and solution stability under room temperature was examined.

Results: The results demonstrated that the FCA and SL in powder form could inactivate AIV and NDV even in the absence or presence of organic materials. In the liquid form, $5 \%$ and $10 \%$ of FCA could inactivate AIV and NDV either in the absence or presence of organic materials. Alongside, 1\%, 5\%, and 10\% of SL could inactivate both viruses. 10\% of FCA solution could inactivate virus at a shortest time when compared with other concentrations. In addition, the efficacy of wetdry conditions of FCA was limited when compared with SL. On the other hand, it is demonstrated that the FCA solution was more stable and kept at room temperature longer than SL.
\end{abstract}

Conclusion: The FCA may, hence, be used as an alternative virucide, while applying it to prevent spreading of poultry disease on commercial chicken farms and also backyard chickens, especially in developing countries, including in rural areas of Thailand.

Keywords: alkaline agent, fresh charcoal ash, slaked lime, virucidal activity.

\section{Introduction}

Several viral diseases, especially avian influenza (AI) and Newcastle disease, have a strong negative impact on commercial chicken. Normally, the related viruses are shed from the respiratory and gastrointestinal systems of clinically or sub-clinically infected birds and circulate in the environment. Biosecurity on farms, such as cleaning and disinfection, is one of the best instruments to reduce the microbial load generally and the level of pathogens in particular, in poultry farms $[1,2]$, especially the mentioned viruses. In general, several organic solvents, detergents, and disinfectants are applied for microorganism inactivation;

Copyright: Ruenphet, et al. Open Access. This article is distributed under the terms of the Creative Commons Attribution 4.0 International License (http://creativecommons.org/licenses/ by/4.0/), which permits unrestricted use, distribution, and reproduction in any medium, provided you give appropriate credit to the original author(s) and the source, provide a link to the Creative Commons license, and indicate if changes were made. The Creative Commons Public Domain Dedication waiver (http:// creativecommons.org/publicdomain/zero/1.0/) applies to the data made available in this article, unless otherwise stated. however, their efficacy is decreased when contaminated with organic materials [2]. There were several trials to outline alternative materials for biosecurity enhancement, which are not affected by organic materials contamination. Several researchers adapted the alternative materials for biosecurity enhancement in spite of the presence of organic material contamination, using alkaline agents such as slaked lime (SL), bioceramic powder [3], scallop shell powder [3], calcinated eggshell [4], and nano-sized scallop shell powder [2].

Charcoal ash or wood ashes are waste products from restaurants and household after cooking, which have alkaline compounds such as calcite (calcium carbonate $\left.\left[\mathrm{CaCO}_{3}\right]\right)$, lime $(\mathrm{CaO})$, and portlandite calcium hydroxide $\left(\mathrm{Ca}[\mathrm{OH}]_{2}\right)[5,6]$. The alkalinity of charcoal ash is high, with $\mathrm{pH}$ from 9.3 to 13.5 [5].

The aims of the present study were to evaluate virucidal efficacies of fresh charcoal ash (FCA) against various chicken pathogens such as AIV and Newcastle disease virus (NDV), either in the absence 
or presence of organic materials, to evaluate their stability under wet and dry conditions, and to appraise solution stability for biosecurity application in chicken farms.

\section{Materials and Methods Ethical approval \\ Ethical approval is not applicable to this study. \\ Sample preparation}

The FCA powders prepared by burning wood charcoal and SL (Zapco ${ }^{\circledR}$, Homeinter supply Co., Ltd., Nonthaburi, Thailand) were used for the present study. Both solution samples were prepared as $1 \%, 5 \%$, and $10 \%$ dilutions using distilled water. A quantity of 1,5 , or $10 \mathrm{~g}$ of each powder was added to $100 \mathrm{ml}$ of $\mathrm{dW}_{2}$ and centrifuged at $1750 \times \mathrm{g}$ for $10 \mathrm{~min}$. The resulting supernatants were used as $1 \%, 5 \%$, or $10 \%$ solutions as described [4].

\section{Viruses and cells}

Low pathogenic AI virus, namely $\mathrm{A} / \mathrm{duck} /$ Aomori/395/04 H7N1 [7], and virulent vNDV, namely NDV/chicken/Asean Country/2013 [8], were propagated in chicken embryonic eggs. After allantoic fluid harvesting, stock viruses were aliquoted and kept at $-80^{\circ} \mathrm{C}$ for testing. Madin-Darby canine kidney (MDCK) cells and chicken embryo fibroblasts (CEF) were used for AIV and NDV titration, respectively.

\section{Powder reaction}

To determine virus inactivation, $200 \mathrm{mg}$ of FCA or SL powders were mixed with $100 \mu$ l of AIV or NDV in the absence of organic material. In addition, for evaluating the presence of organic materials, $100 \mu \mathrm{l}$ of each virus was mixed with $50 \mu \mathrm{l}$ of fetal bovine serum (FBS), and then the mixture was added to $300 \mathrm{mg}$ of each powder sample. After $3 \mathrm{~min}$ incubation at room temperature, the viruses were recovered with $900 \mu 1$ or $850 \mu 1$ of PBS, respectively, then centrifuged at $17,400 \times \mathrm{g}$ for $3 \mathrm{~min}$, and titrated onto MDCK cells or CEF for virus recovering [4].

\section{Liquid reaction}

About $400 \mathrm{~mL}$ of $1 \%, 5 \%$, or $10 \%$ solution samples were mixed with $100 \mu$ of each virus and then incubated at room temperature for an indicated time such as $5 \mathrm{~s}, 30 \mathrm{~s}, 1 \mathrm{~min}, 3 \mathrm{~min}, 5 \mathrm{~min}, 10 \mathrm{~min}$, $30 \mathrm{~min}, 1 \mathrm{~h}$, or $2 \mathrm{~h}$. After that, the mixed solution $\mathrm{pH}$ was neutralized with $500 \mu \mathrm{l}$ of $1 \mathrm{M}$ Tris- $\mathrm{HCl} \mathrm{pH} \mathrm{7.2.}$ Each sample treatment was titrated onto MDCK cells or CEF for AIV or NDV, respectively. $500 \mu 1$ of FBS was added to $10 \mathrm{ml}$ of each sample concentration as $5 \%$ organic materials representation. To confirm the neutralizing efficacy of Tris- $\mathrm{HCl}$, it was added to each solution sample before virus adding, namely at $0 \mathrm{~s}$. Each treatment was tested in triplicates, and the titers were shown in mean with standard error (mean $\pm \mathrm{SE})$.

\section{Virus titration}

Each treated virus was diluted in 10-fold serial dilution using Eagle's minimum essential medium (MEM, Nissui Pharmaceutical Co., Ltd., Tokyo,
Japan) and inoculated onto MDCK or CEF cells containing equal volume of MEM with trypsin (Trypsin, Sigma, St. Louis, MO, U.S.A.) reaching final concentrations of 0.5 and $0 \mu \mathrm{g} / \mathrm{ml}$, respectively. All of the inoculated cell plates were incubated at $37^{\circ} \mathrm{C}$ in $5 \%$ $\mathrm{CO}_{2}$ incubator and observed for the cytopathic effect twice a day for 3 days. At the end of the incubation period, the hemagglutinin activity of the culture supernatant was tested using $0.5 \%$ chicken red blood cells. The $50 \%$ tissue culture infectious dose $\left(\mathrm{TCID}_{50} / \mathrm{ml}\right.$ ) was determined by Behrens and Kärber's method [2].

\section{Stability}

The virucidal activity of FCA and SL stored under harsh conditions using wet-dry environmental transitions was also evaluated. A quantity of $3 \mathrm{~g}$ of FCA or SL powder in a $90-\mathrm{mm}$ Petri dish was used for making suspensions in $10 \mathrm{~mL}$ with tap water, and the dish was kept at $37^{\circ} \mathrm{C}$ incubator for complete drying. The dried sample was collected and tested by powder reaction method. Resuspension and drying were repeated until virucidal efficacy ceased.

The stability of the solution sample was evaluated at 2, 4, 6, and 8 weeks post preparing and keeping at room temperature. Virus inactivation was determined within a 3-min incubation period.

\section{Inactivation analysis}

The reduction factor (RF) was used for determining virus inactivation. The RF is calculated using the following equation: $R F=t_{p c}-t_{a}$; where $t_{p c}$ is the titer converted into an index in $\log _{10}$ of the positive control, and $t_{a}$ is the converted titer an index in $\log _{10}$ of the recovered virus from the treated sample. Inactivation of the virus was considered effective when RF was $\geq 3$ $\log _{10}[2,9,10]$.

\section{Statistical analysis}

The SE is the standard deviation of virus titer distribution. SE was calculated by standard deviation using Microsoft Excel.

\section{Results}

The $\mathrm{pH}$ of $1 \%, 5 \%$, and $10 \%$ FCA solutions was recorded by $\mathrm{pH}$ paper strip as $12.0,12.5$, and 13.0 , respectively, while the overall concentration of SL was measured to be 12.5 .

Table-1 shows that either FCA or SL powders could inactivate AIV and NDV both in the absence and presence of organic materials and reduced the virus titer to below the detection limit $\left(2.5 \log _{10} \mathrm{TCID}_{50} / \mathrm{ml}\right)$.

The AIV inactivation is shown in Table-2. At 5\% and $10 \%$, FCA without organic material contamination could inactivate AIV within $30 \mathrm{~min}$ and $30 \mathrm{~s}$, respectively. Even in the presence of organic materials, inactivation occurred within $2 \mathrm{~h}$ and $1 \mathrm{~min}$, respectively. However, all concentrations of SL could inactivate AIV in the absence and presence of organic materials within $10 \mathrm{~min}$ and $30 \mathrm{~min}$, respectively (Table-2).

Table-3 shows NDV inactivation using both solution samples. In the absence of organic material 

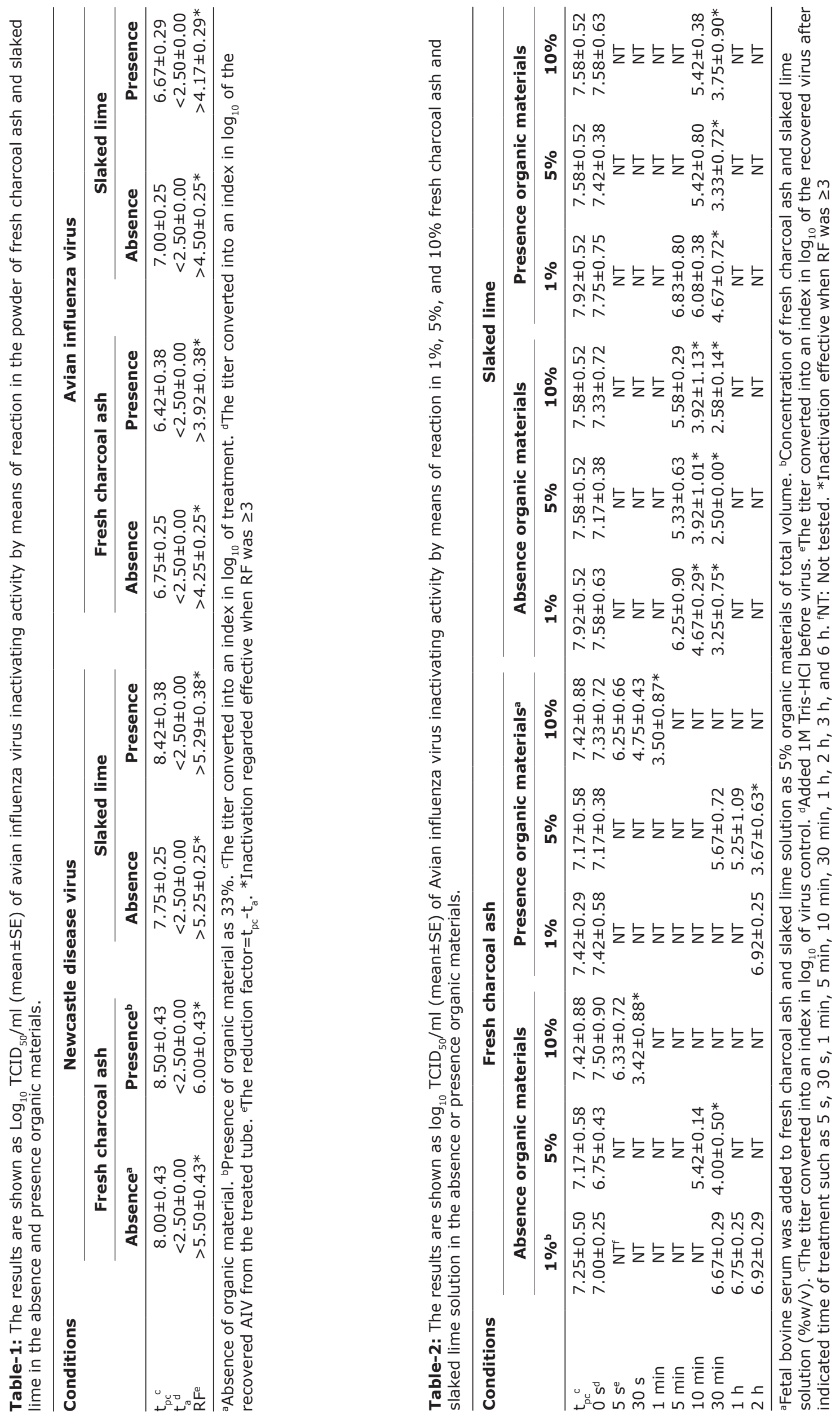


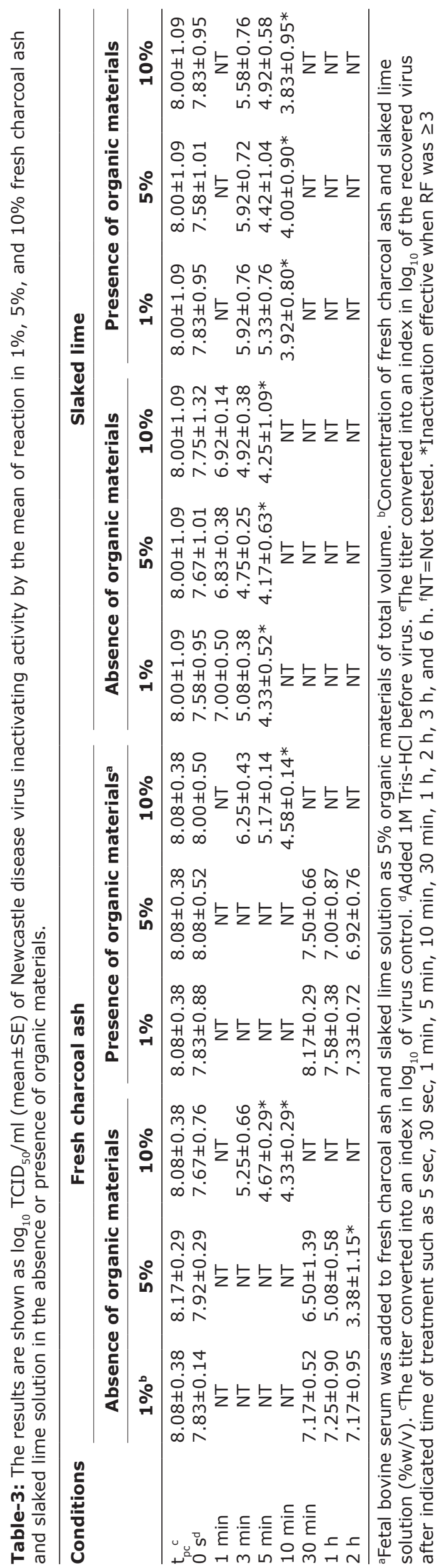

of $5 \%$ and $10 \%$, FCA solution could inactivate NDV within $2 \mathrm{~h}$ and $5 \mathrm{~min}$, respectively. However, even in the presence of organic material of $10 \%$ FCA inactivated NDV within $10 \mathrm{~min}$. Alongside, all concentrations of SL could inactivate NDV in the absence and presence of organic materials within $5 \mathrm{~min}$ and 10 min, respectively (Table-3).

Under the wet and dry conditions during a 3-min incubation period, FCA was demonstrated to effectively inactivate AIV or NDV when resuspended 1 and 2 times, respectively; however, SL was found effective when resuspended 12 and 9 times, respectively (Table-4). In addition, the stability of the sample solution is shown in Table-5. FCA solution still inactivates AIV and NDV after preparing and keeping it at room temperature for at least 8 weeks as $10 \%$ solution, while as SL could inactivate AIV at $10 \%$ solution at 4-week post preparing and at least 2 weeks for NDV inactivation at 10\% (Table-5).

\section{Discussion}

The FCA or wood ash is the residue powder left after the combustion of wood, such as burning wood in a home fireplace or an industrial powder plant. The largest component of charcoal ash (about 25\%) is $\mathrm{CaCO}_{3},<10 \%$ is potash, and $<1 \%$ phosphate $[5,6,11]$. However, there are trace elements of iron, manganese, zinc, copper, and some heavy metals [11]. All of these are, primarily, in the form of oxides [12]. In addition, Demeyer et al. [5] and Tarun et al. [6] described the FCA as strong alkaline that contains main inorganic materials such as calcium oxide and $\mathrm{Ca}[\mathrm{OH}]_{2}$. In water, calcium oxide changes to $\mathrm{Ca}[\mathrm{OH}]_{2}[3]$, which has the ability by means of hydroxyl ion, to damage bacterial cytoplasmic membrane, cause protein denaturation by breakdown the ionic bonds, and damage DNA strand [13]. In the present study, it was shown that high $\mathrm{pH}$ of all FCA solutions could inactivate pathogens, mostly; however, when neutralized by Tris- $\mathrm{HCl}$ before treated, all solutions could not inactivate all pathogens. These results indicated that high $\mathrm{pH}$ underlies an important mechanism for inactivation, and Tris- $\mathrm{HCl}$ was used as an instrument for determination of exposure or contact time in the present study.

The SL is an inorganic compound, practically containing $>70 \% \mathrm{Ca}[\mathrm{OH}]_{2}$. In general, $\mathrm{Ca}[\mathrm{OH}]_{2}$ is a strong alkaline substance. Most of the enteropathogens are unable to survive in this high alkaline environment [14]. In general, SL is widely used as a disinfectant and involves problems associated with its use, such as corrosion and human irritation. The disinfection mechanism of SL is thought to act due to its high $\mathrm{pH}$ [15]. The present study showed virucidal ability of SL which affected to viruses in powder form and solution form.

In general, several disinfectants such as chlorine and quaternary ammonium compounds could not inactivate bacteria and viruses when contaminated with organic materials. However, the FCA and 
Table-4: The RF $\left(\log _{10} \mathrm{TCID}_{50} / \mathrm{ml}\right)$ of fresh charcoal ash and slaked lime applied for inactivating Newcastle disease virus and Avian influenza virus under wet and dry conditions at consecutive re-suspension times with a 3-min incubation period.

\begin{tabular}{|c|c|c|c|c|}
\hline \multirow{2}{*}{$\begin{array}{l}\text { Number of times } \\
\text { resuspended }\end{array}$} & \multicolumn{2}{|c|}{ Avian influenza virus } & \multicolumn{2}{|c|}{ Newcastle disease virus } \\
\hline & Fresh charcoal ash & Slaked lime & Fresh charcoal ash & Slaked lime \\
\hline 1 & $>5.00 *$ & $>4.75^{*}$ & $>5.75^{*}$ & $>5.00 *$ \\
\hline 2 & 0.50 & $>4.75^{*}$ & $5.25^{*}$ & $>5.50 *$ \\
\hline 3 & 0.50 & $>4.75^{*}$ & 0.00 & $>5.50 *$ \\
\hline 4 & 0.50 & $>4.75^{*}$ & 0.50 & $>5.50 *$ \\
\hline 5 & 0.50 & $>4.75^{*}$ & NT & $>5.50 *$ \\
\hline 6 & NT & $>5.00 *$ & NT & $>5.50 *$ \\
\hline 7 & NT & $>5.00 *$ & NT & $>5.50 *$ \\
\hline 8 & NT & $>5.00 *$ & NT & $3.25 *$ \\
\hline 9 & NT & $>5.00 *$ & NT & $3.75^{*}$ \\
\hline 10 & NT & $>5.00 *$ & NT & 2.50 \\
\hline 11 & NT & $>5.00 *$ & NT & 1.00 \\
\hline 12 & NT & $>4.75^{*}$ & NT & 0.00 \\
\hline 13 & NT & 2.50 & NT & NT \\
\hline 14 & NT & 2.25 & NT & NT \\
\hline 15 & NT & 1.75 & NT & NT \\
\hline
\end{tabular}

*Inactivation regarded effective when $\mathrm{RF}$ was $\geq 3, \mathrm{RF}=$ Reduction factor

Table-5: The RF $\left(\log _{10} \mathrm{TCID}_{50} / \mathrm{ml}\right)$ of fresh charcoal ash and slaked lime solution applied for inactivating Newcastle disease virus and Avian influenza virus after being kept at room temperature with a 3-min incubation period.

\begin{tabular}{|c|c|c|c|c|c|}
\hline \multirow{2}{*}{$\begin{array}{l}\text { Time point } \\
\text { (week) }\end{array}$} & \multirow[t]{2}{*}{ Concentration (\%) } & \multicolumn{2}{|c|}{ Avian influenza virus } & \multicolumn{2}{|c|}{ Newcastle disease virus } \\
\hline & & Fresh charcoal ash & Slaked lime & Fresh charcoal ash & Slaked lime \\
\hline \multirow[t]{3}{*}{2} & 1 & 0.50 & 0.50 & 0.50 & 0.50 \\
\hline & 5 & 0.50 & 2.50 & 1.75 & 0.50 \\
\hline & 10 & $3.5^{*}$ & $3.75 *$ & $>5.50 *$ & 0.50 \\
\hline 4 & 10 & $3.50 *$ & $3.25 *$ & $>4.25 *$ & NT \\
\hline 6 & 10 & $3.25 *$ & NT & $>5.25 *$ & NT \\
\hline 8 & 10 & $3.25 *$ & NT & $>5.0 *$ & NT \\
\hline
\end{tabular}

*Inactivation regarded effective when $\mathrm{RF}$ was $\geq 3, \mathrm{RF}=$ Reduction factor

SL could inactivate AIV and NDV even in the presence of organic materials in the present study. These findings are compatible with results obtained by several researchers which tested alkaline agents such as food additive $\mathrm{Ca}[\mathrm{OH}]_{2}$ ( $\mathrm{pH}$ 12.5) and SL (pH12.5); that showed virucidal effect toward NDV [16]; calcinated eggshell powder (pH12.7), that showed virucidal ability against NDV, AIV and infectious bursal disease virus $[4,17]$; as well as scallop shell powder ( $\mathrm{pH}$ 13.0) and SL that could inactivate AIV [3]. Lorcharoenrungroj et al. [18] reported that FCA could inactivate AIV, Escherichia coli, and Salmonella infantis in the presence of organic material and those findings are related to the present study. Finally, not only alkaline agent that could inactivate viruses even in the presence of organic material but also acidic agents were pointed at by Sonthipet et al. [8], who described the bactericidal and virucidal efficacies of potassium monopersulfate ( $\mathrm{pH} 2.04$ ); this acidic agent also inactivated AIV on virus-spiked clothes.

In addition, the wet-dry conditions and the stability of the solution sample were illustrated and lasted long enough to inactivate AIV and NDV under both conditions. The efficacy of wet-dry conditions of FCA is limited when compared with SL. This result indicated that the stability of FCA powder is not steady, especially in the rainy season, when FCA powder may be washed or soaked by rain, thereupon being affected similarly to the wet conditions in the present study. On the other hand, it was demonstrated that the FCA solution was more stable and kept at room temperature longer than SL. These stability results may be applied, suggesting an alternative disinfectant agent, especially for biosecurity enhancement on and around chicken farms.

\section{Conclusion}

Both powder and solution forms of FCA and SL could inactivate AIV and NDV under various concentrations, organic material presence, and during exposure or contact timing. Thereby, FCA might be used as an alternative material, while applying it to prevent spreading of poultry disease on commercial chicken farms and also backyard chickens, especially in developing countries, including in rural areas of Thailand.

\section{Authors' Contributions}

KT supervised the present study. SR designed and coordinated the study. TJ, SR, DP and KT performed the experiment. SR analyzed the data and wrote the manuscript. The final manuscript has been read and developed in consultation with all authors. 


\section{Acknowledgments}

The authors thank Dr. Dany Shoham, Bar Ilan University, Israel, for the grammatical review of the manuscript. This work was supported in part by a grant number 60-VET-DVM-4.1-014 in aid from Veterinary Medicine Faculty, Mahanakorn University of Technology (MUT), Thailand, and Faculty of Agriculture, Tokyo University of Agriculture and Technology.

\section{Competing Interests}

The authors declare that they have no competing interests.

\section{Publisher's Note}

Veterinary World remains neutral with regard to jurisdictional claims in published institutional affiliation.

\section{References}

1. Gehan, Z.M., Anwer, W., Amer, H.M., EL-Sabagh, I.M., Rezk, A. and Badawy, E.M. (2009) In vitro efficacy comparisons of disinfectants used in the commercial poultry farms. Int. J. Poult. Sci., 8(3): 237-241.

2. Thammakarn, C., Satoh, K., Suguro, A., Hakim, H., Ruenphet, S. and Takehara, K. (2014) Inactivation of avian influenza virus, Newcastle disease virus and goose parvovirus using solution of nano-sized scallop shell powder. J. Vet. Med. Sci., 76(9): 1277-1280.

3. Thammakarn, C., Tsujimura, M., Satoh, K., Hasegawa, T., Tamura, M., Kawamura, A., Ishida, Y., Suguro, A., Hakim, H., Ruenphet, S. and Takehara, K. (2015a) Efficacy of scallop shell powders and slaked lime for inactivating avian influenza virus under harsh conditions. Arch. Virol., 160(7): 2577-2581.

4. Ota, M., Toyofuku, C., Thammakarn. C., Sangsriratanakul, N., Yamada, M., Nakajima, K., Kitazawa, M., Hakim, H., Alam, S., Shoham, D. and Takehara, K. (2016) Calcinated egg shell as a candidate of biosecurity enhancement material. J. Vet. Med. Sci., 78(5): 831-836.

5. Demeyer, A., Voundi, N.J.C. and Verloo, M.G. (2001) Characteristics of wood ash and influence on soil properties and nutrient uptake: An overview. Bioresour. Technol., 77(3): 287-295.

6. Tarun, R., Kraus, R.N. and Kumar, R. (2003) A new source of pozzolanic material. Concr. Int., 25(12): 55-62.

7. Jahangir, A., Ruenphet, S., Shoham, D., Okamura, M., Nakamaura, M. and Takehara, K. (2010) Haemagglutinin and neuraminidase characterization of low pathogenic $\mathrm{H} 5$ and $\mathrm{H} 7$ avian influenza viruses isolated from Northern pintails (Anas acuta) in Japan, with special reference to genomic and biogeographical aspects. Virus Genes, 40(1): 94-105.

8. Sonthipet, S., Ruenphet, S. and Takehara K. (2018) Bactericidal and virucidal efficacies of potassium monopersulfate and its application for inactivating avian influenza virus on virus-spiked clothes. J. Vet. Med. Sci., 80(4): 568-573.

9. Lombardi, M.E., Ladman, B.S., Alphin, R.L. and Benson, E.R. (2008) Inactivation 323 of avian influenza virus using common detergents and chemicals. Avian Dis., 52(1): 118-123.

10. Takehara, K., Yamazaki, K., Miyazaki, M., Yamada, Y., Ruenphet, S., Jahangir, A., Shoham, D., Okumura, M. and Nakamura, M. (2010) Inactivation of avian influenza virus H1N1 by photocatalyst under visible light irradiation. Virus Res., 151(1): 102-103.

11. Lerner, B.R. (2000) Wood Ash in the Garden. Purdue University, Department of Horticulture and Landscape Architecture, West Lafayette, IN, USA.

12. Misra, M.K., Ragland, K.W. and Baker, A.J. (1993) Wood ash composition as a function of furnace temperature. Biomass Bioenergy, 4(2): 103-116.

13. Siqueira, J.F. and Lopes, H.P. (1999) Mechanisms of antimicrobial activity of calcium hydroxide: A critical review. Int. Endod. J., 32(5): 361-369.

14. Aiello, S. (1998) The Merck Veterinary Manual. $8^{\text {th }}$ ed. Merck \& Co, Whitehouse Station. NJ, USA.

15. Takehara, K., Chinen, O., Jahangir, A., Miyoshi, Y., Ueno, Y., Ueda, S., Takada, Y., Ruenphet, S., Mutoh, K., Okamura, M. and Nakamura, M. (2009) Ceramic powder made from chicken feces: Anti-viral effects against avian influenza viruses. Avian Dis., 53(1): 34-38.

16. Paditporn, K., Ruenphet, S. and Takehara, K. (2016) Comparison of Virucidal Effects for the Newcastle Disease Virus between Slaked Lime and Food Additive Calcium Hydroxide. In: Proceedings of the $9^{\text {th }}$ MUT Veterinary Annual Conference 2016, Mahanakorn University of Technology, Bangkok, Thailand. p13-18.

17. Thammakarn, C., Ishida, Y., Suguro, A., Hakim, H., Nakajima, K., Kitazawa, M. and Takehara, K. (2015b) Inhibition of infectious bursal disease virus transmission using bioceramic derived from chicken feces. Virus Res., 204(9): 6-12.

18. Lorcharoenrungroj, K., Takehara, K. and Ruenphet, S. (2016) Studies on Fresh Charcoal Ash to Inactivate Avian Influenza Virus, Escherichia coli and Salmonella Infantis for Biosecurity Enhancement On Chicken Farms. In: Proceedings of the $9^{\text {th }}$ MUT Veterinary Annual Conference 2016, Mahanakorn University of Technology, Bangkok, Thailand. p5-12. 